\title{
Do we have the right toolbox? A process of mixed methods: a research case from an urban transformation site in Istanbul
}

\author{
Ö. Özçevik ${ }^{1} \&$ P. $\operatorname{Tan}^{2}$ \\ ${ }^{1}$ Urban and Regional Planning Department, \\ Istanbul Technical University, Turkey \\ ${ }^{2}$ New Media Department, Kadir Has University, Turkey
}

\begin{abstract}
Since 2000, cities have been undergoing rapid and forced transformations initiated both by real estate markets and governments. Within the context of such developments, urban researchers often focus on sites and communities or specific spatial-classes. Fast-changing and heterogeneous conditions have called attention to the proper usage of research methods. Both from a technical and ethical perspective, obtaining quantitative and qualitative data does not necessarily provide the requisite knowledge and information in such cases. This paper aims to question the urban research methodologies that have been employed in contested urban spaces and heterogeneous spatial urban sites by asking: How can quantitative and qualitative data be proven? How can data capturing the intentions of local actors be determined? How and when should mixed-research methods be used to address specific urban situational conditions? What is the actual research process like? What are the failures or outcomes of current research methodologies? This paper will present the research experiences from a specific site of Istanbul, Kağlthane. The argument of this paper is that several qualitative research tools can be invented or used; however, the situational urban condition is the phenomenon to which tools should be adapted, or they should be invented according to the contextual conditions. The first half of the paper discusses a mixed-methods approach and then takes up the issue of notion of changing urban conditions. The second half covers the empirical basis and concludes with a synthesis of the ideas discussed.
\end{abstract}

Keywords: mixed methods, urban site research, urban transformation, Kă̆lthane (Istanbul). 


\section{Introduction}

In this paper we aim to discuss the outcome of the usage of mixed-methods in our research through the example of Kağıthane (a district in Istanbul, Turkey). Kağtthane is one of many urban areas that was initially built as a "gecekondu" and was subsequently transformed through legal processes under the influence of local political agendas in the 1980s. Nowadays, this area is one of the townships of Istanbul, which has been subject to projects of state-led transformation. In Turkey, such urban transformation projects are directly linked and understood to be an activity of the real estate market. The application and operations of urban transformation processes not only mean the "creation of sustainable urban policies” but also preserving local urban practices and inhabitant participation. However, the entire process in Turkey is strongly connected to urban policy creation, justification of property expropriation and urban rescaling. There are two main problems in the context of site research in such a field, the first of which is finding and revealing local knowledge, which is embedded in sociospatial networks. The complexity of this embedded socio-spatial knowledge is often dismissed or not understood by the local authorities and government, which are launching and applying urban transformation policies in Turkey. This paper, which is based on our site research of Kağithane (as the socio-spatial aspect of an integrated study titled "The Impacts of Urban Transformation: An ITU study of Kağtthane”), aims to reveal and analyze the embedded local knowledge of the site. Furthermore, the overall research focuses on the impacts and perceptions of inhabitants regarding their expectations of urban transformation projects, which are undertaken by the central government. The three main neighborhoods that we selected are Çeliktepe, Nurtepe and Talatpaşa, which are lower mixed income areas with a diverse ethnic population. Recently, the area has been subject to urban earthquake policy, which allows municipalities to transfer properties, transform the built environment and scale urban populations. For that reason we argue that without researching and analyzing the local embedded knowledge in this specific urban network, it is impossible to create a sustainable and inclusive urban methodology during the urban transformation process for the reason that such state-led urban transformation projects often undermine this local knowledge.

The central methodological approach of this research was based on a search for the embedded knowledge in the socio-spatial network of Kağıthane. As a form of mixed-methods research, both quantitative and qualitative methods were applied subsequently and in parallel. A survey of 1,013 inhabitants, focus groups for different income levels, research into social identity backgrounds and deep interviews were utilized in this research. The data of the survey was processed through the SPSS program to test the analysis and ANOVA testing was used to determine the significance of the data. 


\section{The urban conditions of Istanbul}

As a rapidly growing city with large demographic expansion, Istanbul is just one of many cities with complex urban textures that since the last century has been subjected to a number of transformative efforts as regards both planning and its socio-spatial aspects. Urban transformation and gentrification projects have been largely initiated in urban sites of Istanbul, both in the historical city centers and peripheral areas. As most projects were initiated and managed by international companies or transnational firms in the 1980s, financial liberalization has brought joint ventures with these firms in collaboration with national capital. Numerous gentrification and urban transformation projects have been developed under the auspices of the real-estate market and economic transformation [1]. Specifically in Turkey, as a result of the decision to launch large-scale financial liberalization in 1989, the influx of capital flows ushered in a neoliberal era and the Turkish state supported the enlargement of the construction sector with new legislation [2]. Urban transformation and redevelopment/renewal projects started to be justified through planning and zoning regulation by TOKI beginning in the year 2000. The TOKİ housing administration department is a governmental unit, which is directly linked to the prime ministry and as such it has a heavily centralized structure. TOKİ oversee the construction of buildings, housing and settlements and invokes legislation to justify property transfers and the expropriation of territories and settled areas. As the main actor in urban transformation projects, TOKI mediates between the state and the construction and real-estate sectors. In particular, the Istanbul Greater Municipality declared urban transformation and renewal areas to be a main item on the agenda in collaboration with TOKİ and several construction firms. Property transfers and expropriation both in housing and land ownership were organized through new zoning plans and related rulings. The mobilization of capital and urban surplus was mobilized through this collaboration of state and housing/construction sectors under the umbrella of urban transformation/renewal policy and has largely resulted in the relocation and eviction of resident populations. Thus, as Harvey has noted often happens, the state moderates and plays a market role in neoliberal urban governmentality: “...generate a complex reconstitution of stateeconomy relation in which state institutions are actively mobilized to promote market-based regulatory arrangements” [3].

\subsection{Earthquake policy and urban transformation policy}

The Marmara earthquake in 1999 brought the realization that Istanbul faces two critical issues. Firstly, there is the risk of future earthquakes. Secondly, it became obvious that many of the buildings in Istanbul are not structurally sound, and there is a need for the transformation and improvement of its physical structures. However, since 1999, solutions to these problems have remained inadequately implemented, and constructive and holistic earthquake-focused urban transformation policies have not been established [4]. As discussed above, Istanbul's urban transformation projects have been rapidly amalgamated with 
neoliberal urban policies. To date, the urban transformation process has been developed by a centralized authoritarian government via centralized policies and its resultant programs. A so-called "Earthquake Policy" was enacted in 2012 with the ostensible aim of supporting (but actually becoming the main part of) activities and programs of urban transformation projects. Act No.6306 - Article concerning the Transformation of Earthquake Risk ("Afet Risk Altındaki Alanların Dönüştürülmesi Hakkında Kanun”, Resmi Gazete, Date: 31.5.2013, Number: 28309). The legislative process and enactment of policies have been treated as projects of urban transformation rather than incorporating grassroots strategies. Thus the social, economical and spatial networks have not been considered to be components of the process, and the local knowledge and data embedded in neighborhood networks have been dismissed by the local authorities. Notably, Kağıthane, the area we selected for our study, was one of the first "gecekondu" neighborhoods dating from around 1955 to be designated for transformation under the terms of the state's earthquake policy in 2012. "Gecekondu” literally means "a dwelling that was built in one night”. It is often used to refer to housing that was built starting in the 1950s in Istanbul, when large-scale migration from Anatolia to the city began. Construction was often carried out by the migrants themselves and residential areas developed spontaneously. Migration in the 1950s to Istanbul was mainly based on labor migration from rural to urban areas of Istanbul as there was a labor shortage in the industrial sectors. In order to provide their own housing, most immigrants quickly built in a self-organized manner their own dwellings and houses ("gecekondu”). Most "gecekondu” areas were legalized under the local political agendas in the 1980s through the delivery the water, electricity and infrastructural support by the local authorities.

\subsection{Features of Kağıthane}

Kağıthane Township, consisting of 19 neighborhoods, is located on the western side of Istanbul and is on the northeastern shore of the Golden Horn. Main highways such as E-5 to the south and the TEM highway to the north, as well as specific crossroads, are important transportation hubs that connect both sides of Istanbul. With a size of 1,500 hectare, Kağtthane is one of the smallest townships of Istanbul. The neighborhood of Çeliktepe is located in the north, and the Nurtepe and Talatpaşa neighborhoods are located on the southwest side of Kağıthane. Demographic reports indicate that the population of Kağıthane increased between 1955 and 1970, while the shift in numbers of residents between 1970 and 2000 is negligible. After 2000, however, we see rapid demographic growth in Kağıthane. Due to large-scale labor migration to Istanbul from Anatolia in the 1950s, most gecekondu areas expanded on the outskirts of Istanbul's urban centers [5]. In this process, peripheries were transformed into urban centers with the expansion of the entire city. Initially, Kağıthane was founded as a village but was officially recognized as a local municipality in 1963 based on territorial and demographic expansion. Kağıthane is located in two valleys, the topographic features of which also influenced the formation and identity of the neighborhoods. 


\section{The importance of mixed methods in complex urban site research: the case of Kağıthane}

Our project, “A Case Study on the Impacts of Urban Transformation: Kağıthane” is based on mixed research methods. The research design was preceded by 13 steps as scheduled and described by Collins: Define the aim of the research, formulate the purposes of the research, determine the research/mixing rationale, determine the purpose of research/mixing, define the research questions, formulate the sample design, select the mixed-methods research design, gather data, carry out data analysis, validate/legitimate the data, interpret the data, and write the report of the outcome of the research [5]. In the empirical research of urban studies, research methodologies are often based on two poles and the research itself. The implementation of quantitative and qualitative methods is often divided according to the design and aims of the research. Especially in urban studies, the research methods are often separated between quantitative and qualitative methods both in the fields of planning and sociology. Demographic surveys, analyses of the social identity of space, planning and parcel information (surveys), GSP mapping and geographical data of the urban population are often used in research that is based on quantitative data gathering. Qualitative methods in urban studies are used more in community research with the participation of local inhabitants and often employ focus groups, deep interviews, participatory action research and community involvement.

Claire Hewson has defined mixed method research as the "combined use of both quantitative and qualitative methodologies within the same study in order to address a single research question" [6]. Furthermore, Creswell contributed to the development of a variety of tools for designing mixed-methods research in his own work: "Mixed methods research is an approach to inquiry that combines or associates both qualitative and quantitative forms of research. It involves philosophical assumptions, the use of qualitative and quantitative approaches, and the mixing of both approaches in a study" [7]. Since there are several research and data designs in the creation of mixed-methods, useful strategies emerge for the researcher. For instance, one strategy is to use quantitative and qualitative methods separately in order to acquire data and subsequently combine and analyze them. As Creswell points out, "Alternatively, the qualitative and quantitative data can be merged into one large database or the results can be used side by side to reinforce each other" [8].

The main aim of our research, which is based on information gathered through quantitative and qualitative data about three neighborhoods located in Kağıthane, is to discuss urban transformation strategies within the context of grassroots information and data on socio-spatial networks. Furthermore, this research aims to point out the importance of the socio-spatial knowledge that should be considered in such urban areas, which are under the pressure of topdown urban transformation planning policies. The reason why we opted to employ mixed social research is that the socio-spatial networks themselves have several mixed components. Such urban environments, which are subject to constant transformation and demographic expansion, have a complex and 
situational socio-spatial network. The identity of communities, the construction process of housing, small economic enterprises, multiple local networks and unstable mixed incomes create a complex and inconsistent social urban setting. Therefore, a flexible research model is needed in order to allow for cross-data collecting methods and analysis that is sensitive to the existing conditions. The spatial definition of Kağtthane in this research includes housing units and local centers of commerce, and the local actors are the inhabitants and local business owners. According to this contextualization, there are two primary components:

- Housing Unit Research: Data on tenants and ownership in the Çeliktepe, Nurtepe, Talatpaşa neighborhoods (these neighborhoods were built up in the 1950s as an outcome of migration flows), and household data.

- Local Commerce Network Research: After the urbanization process, Çeliktepe neighborhood became a main crossroads in Kağıthane connected to other townships. This includes information about local business ownership and the local business sectors in Çeliktepe and their future negotiation with local authorities on urban transformation policy.

The quantitative questions we pose are: In order to elaborate on and set urban transformation strategies, what data on the social-spatial network (space, locality) can be used? What are their components and dynamics? What are the differences among the neighborhoods, which have slightly different identities but are run by the same township government?

Our qualitative questions include: What is the impact of the expectation of urban transformation that influences these neighborhoods? How they are influenced? What kinds of mechanisms do they produce regarding the expectation and pressure of urban transformation policies?

This research uses both concurrent design and sequential design methodologies. Concurrent design is a methodology for data collecting that employs different forms in the acquisition of data that enables us to compare the analysis and test the data in different forms. Sequential design is a strategy of collecting data that uses a repetitive process, and thus such data supports other collected data. Sequential design was useful in defining the most effective target group (for example, participants and inhabitants in focus groups) and subsequently the validity of the data and supporting findings [9]. One of the most important outcomes of this methodology was the effect of the re-design of household data collecting. The outcome of the necessity of adding the new data of the local commerce and small-scale retailer network and interpreting the data together with the household data was more useful in analyzing the commercial crossroads in the neighborhood among the housing and commercial units.

The selection of the neighborhoods for this research was based on recent observations, reports and data. Çeliktepe is a neighborhood that is already transforming (gentrifying) itself within its own dynamics. This neighborhood is also the oldest "gecekondu" and has a specific collateral kinship network. Nurtepe, however, has newly constructed small-scale gated housing units for mixed income, which is a sign of future urban transformation. The most significant feature of this neighborhood is it specific ethnic and kinship network of Alevism (a specific sect of Islam religion). Furthermore, Talatpaşa was based 
on the leftover parcels from the Çeliktepe. This neighborhood is still resisting and has not been transformed yet. It has an active political resistance identity.

The quantitative data for this aspect of the study was acquired by face-to-face surveys with 1,013 participants. A field survey was carried out in collaboration with the SONAR Survey Company and ITU Urban and Regional Planning Students as a summer exercise. Based on basic value (current estimated value of one square meter of land in Kağtthane) and the percentages of ownership-tenants of these neighborhoods, the numbers of interviewees are as follows: 347 in Talatpaşa, 423 in Çeliktepe, and 243 in Nurtepe. For the qualitative data, group meetings were organized by inviting 7-10 inhabitants to three "participatory focus groups" from these neighborhoods. As we were not satisfied with the outcome data of the focus groups, we selected 13 people from all of the focus groups in order to carry out deep interviews with partially open questions. The criteria of selecting and inviting the inhabitants for interviews and conversation were: voluntary participation, age and gender balance, the percentage of ownership and tenants, the balance of wage earner and employer, heterogeneity between education and income level, and duration of residence in the neighborhood. The data concerning focus groups, which dealt with opinions and information and experiences about recent developments in their neighborhoods was not clear as the inhabitants who were represented changed their positions according to the discussions at hand. One of the reasons we defined that arbitrary condition is the lack of knowledge of the recent urban transformation policy (Earthquake Policy) and the lack of confidence under pressure of that policy as well as lack of trust in local governments (researchers' observation).

After collecting the data in the first phase of the research, we selected one of the local commercial areas of the "Çeliktepe Commercial Crossroad" as the special area of research focus in Kağtthane. The second phase of the research involved conducting research on local commerce by meeting and interviewing 164 local business owners. Deep interviews with partially closed questions were conducted with 7 small-scale retailer guild directors. The parameters of the quantitative and qualitative research are indicated in Tables 1 and 2.

\subsection{Findings and analysis}

The result of the analysis of the mixed methods of our site research in Kağithane indicates that the codes of understanding of the urban transformation policy and reality differ in each neighborhood. Not only the diverse social profiles of each neighborhood, but also the different social perceptions of the neighborhoods could affect the application of urban transformation policy in Kağithane. In Table 3, the numbers 1 (low), 2 (middle), 3 (high) represent the results, which indicate the meanings accorded them by the inhabitants of each neighborhood. 
Table 1: Kağıthane housing and household site research quantitative parameters and database.

\begin{tabular}{|c|c|}
\hline DOMAIN PARAMETERS & SUBDOMAIN PARAMETERS \\
\hline Demographic Structure & $\begin{array}{l}\text { Age } \\
\text { Gender } \\
\text { Occupation } \\
\text { Education } \\
\text { Birth place } \\
\text { Migration } \\
\text { Family type }\end{array}$ \\
\hline $\begin{array}{l}\text { Work Life } \\
\text { Economical Structure }\end{array}$ & $\begin{array}{l}\text { Profession } \\
\text { Labor Force } \\
\text { Length of Employment } \\
\text { Income } \\
\text { Social Security } \\
\text { Social Benefits } \\
\end{array}$ \\
\hline $\begin{array}{l}\text { Housing } \\
\text { (Physical Condition) }\end{array}$ & $\begin{array}{l}\text { Building Typology } \\
\text { Rooms } \\
\text { Consumer Goods } \\
\text { Transition/time }\end{array}$ \\
\hline Housing (Property) & $\begin{array}{l}\text { Property } \\
\text { Length of Period of Residence } \\
\text { Types of Ownership of Property (land owner, } \\
\text { proprietor, shareholder) } \\
\text { Possession of Real-Estate Goods (other) } \\
\text { Satisfactory (Housing) } \\
\text { Expectation (Housing) }\end{array}$ \\
\hline $\begin{array}{l}\text { Housing } \\
\text { (Surrounding, Neighborhood) }\end{array}$ & $\begin{array}{l}\text { Choice } \\
\text { Usage of Facilities } \\
\text { Changing Places } \\
\text { Security } \\
\text { Crime } \\
\end{array}$ \\
\hline Neighborhood/Community & $\begin{array}{l}\text { Belonging } \\
\text { Solidarity } \\
\text { Decision Making } \\
\text { Community Membership }\end{array}$ \\
\hline Participation & $\begin{array}{l}\text { Citizen Participation } \\
\text { Civil Participation } \\
\text { Anchoring Inhabitant/Family/Neighborhood }\end{array}$ \\
\hline Urban Transformation & $\begin{array}{l}\text { Information } \\
\text { Level/Description/Perception/Preference/Expectation } \\
\text { Legal Conformity of Housing } \\
\text { Preference for Transformation } \\
\text { Housing/Neighborhood } \\
\text { Objection } \\
\text { Relinquishment of Rights } \\
\text { Institutional Perception/Trust } \\
\text { Change of Location }\end{array}$ \\
\hline
\end{tabular}


Table 2: Kağıthane housing and household site research qualitative parameters and database.

\begin{tabular}{|c|c|}
\hline DOMAIN PARAMETERS & $\begin{array}{l}\text { SUBDOMAIN } \\
\text { PARAMETERS }\end{array}$ \\
\hline \multirow[t]{2}{*}{ Migration Narratives } & Istanbul \\
\hline & Neighborhood \\
\hline $\begin{array}{l}\text { Satisfaction of Housing and } \\
\text { Neighborhood }\end{array}$ & $\begin{array}{l}\text { Housing and Nearby Physical } \\
\text { Surroundings }\end{array}$ \\
\hline \multirow{4}{*}{ Social Network, Participation, Gender } & $\begin{array}{l}\text { Forms of Social Relations Networks } \\
\text { Organization } \\
\text { Exclusion }\end{array}$ \\
\hline & Social Risk and Vulnerability \\
\hline & $\begin{array}{l}\text { Participation, Communication, and } \\
\text { Conciliation } \\
\text { Participation in Public Space } \\
\text { Citizenship Participation } \\
\text { Cyber Participation }\end{array}$ \\
\hline & Gender \\
\hline $\begin{array}{l}\text { Local Authorities' Perceptions and } \\
\text { Community Needs }\end{array}$ & $\begin{array}{l}\text { Trust } \\
\text { Expectation }\end{array}$ \\
\hline $\begin{array}{l}\text { Urban Transformation Perceptions and } \\
\text { Expectations of its Policy }\end{array}$ & $\begin{array}{l}\text { Information Level } \\
\text { Central and Local Authorities } \\
\text { Physical } \\
\text { Social } \\
\text { Economical } \\
\text { Environmental } \\
\end{array}$ \\
\hline
\end{tabular}

\section{Conclusion}

\subsection{Locating data}

In this mixed-method based research, the site of a defined urban transformation area (as determined by the local and central authorities) of Kağithane was analyzed in terms of the existing recent socio-spatial data and perceptions and expectations of the inhabitants concerning the urban transformation policy. We located and contextualized the data according to the questionable potentialities of the future urban transformation process and its policy. Data concerning the socio-spatial networks and the embedded knowledge of the place of Kağithane are necessary for a sustainable urban transformation process, which satisfies mutual needs (of both the inhabitants and local authorities). Furthermore:

- In urban studies, designing mixed method methodologies for such heterogeneous and situational urban networks is necessary in order to reveal the embedded knowledge of the urban place.

- This research analysis is an iterative and ongoing process.

- In the process of urban transformation in Kağıthane, the local network of commerce should be included and considered along with households. 
Table 3: Quantitative parameters and database for workplaces and local guilds in Kağıthane.

\begin{tabular}{|c|c|}
\hline DOMAIN PARAMETERS & SUBDOMAIN PARAMETERS \\
\hline Demographic Structure & $\begin{array}{l}\text { Age } \\
\text { Gender } \\
\text { Occupation } \\
\text { Education } \\
\text { Birth } \\
\text { Social Security } \\
\text { Inhabiting Neighborhood }\end{array}$ \\
\hline Management Worker Profile & $\begin{array}{l}\text { Gender } \\
\text { Length of Employment } \\
\text { Profession } \\
\text { Education } \\
\text { Place of Residence } \\
\text { Means of Transportation to Work }\end{array}$ \\
\hline Operations Profile & $\begin{array}{l}\text { Type of Building } \\
\text { Location } \\
\text { Property } \\
\text { Amount of Rent } \\
\text { Size of Plot } \\
\text { Sector } \\
\text { Length of Operations }\end{array}$ \\
\hline $\begin{array}{l}\text { Location of Operations, Local Logistics, } \\
\text { Service Hinterland }\end{array}$ & $\begin{array}{l}\text { Choice of Location } \\
\text { Level of Satisfaction } \\
\text { Difficulties } \\
\text { Acquisition of Goods } \\
\text { Customer Profile } \\
\text { Existence of Black Market Operations }\end{array}$ \\
\hline Future Plan of Operations & $\begin{array}{l}\text { Increase of Capacity } \\
\text { Human Resources } \\
\text { Increased Space } \\
\text { Change of Location } \\
\text { Change in Sector } \\
\end{array}$ \\
\hline Urban Transformation & $\begin{array}{l}\text { Perceptions } \\
\text { Demands-Expectations-Relinquishments }\end{array}$ \\
\hline $\begin{array}{lrr}\text { Legal Issues } & \text { Concerning } & \text { Urban } \\
\text { Transformation } & & \end{array}$ & $\begin{array}{l}\text { Level of Being Informed } \\
\text { Source of Information Obtained } \\
\text { Expectations for Policies } \\
\text { Expectations of Participation Level }\end{array}$ \\
\hline Local Guild & $\begin{array}{l}\text { Shared Decision-Making Ability } \\
\text { Trust Level }\end{array}$ \\
\hline Urban Transformation Launch Strategies & $\begin{array}{l}\text { Housing and Commerce, Culture } \\
\text { Increase in Trade Capacity } \\
\text { Use of Loan Funds } \\
\text { Participatory Approaches } \\
\text { Environment of Trust }\end{array}$ \\
\hline
\end{tabular}


- Social and economical policy and the initial steps of a grassroots, participatory urban transformation process should only be made with the data of the embedded local knowledge of the place and socio-spatial network.

- Applying mixed methods is necessary and useful in such complex urban sites which are under pressure and the threat of top-down transformation policies. However, some criticisms of mixed methods should be taken into account, and these are indicated below.

Table 4: Quantitative parameters and database for workplaces and local guilds in Kağıthane.

\begin{tabular}{|l|}
\hline DOMAIN PARAMETERS \\
\hline Local Trade, Current and Future \\
\hline Current Employment Capacity \\
\hline Urban Transformation Information \\
\hline Urban Transformation Perceptions \\
\hline Urban Transformation and Communication among Guilds \\
\hline Expectations of Local Authorities \\
\hline Urban Transformation and Management Plan Operations \\
\hline General Physical Condition, Location, Structure, Types, Property and Social Relations \\
\hline Urban Transformation and Physical, Social and Economic Impact. \\
\hline
\end{tabular}

\subsection{Criticisms of mixed methods and capture of truth}

Collecting data with mixed methods is known to have both advantages and disadvantages [10]. Open, semi-open and constructed questionnaires can be problematic in analyzing the results and building up a comparative source. In such cases, the research team should exercise extreme caution. In our case, the sequential method worked well and the outcome resulted in concrete knowledge of the local place. Because the needs of the local business community were seen as being a necessary aspect of data to facilitate analysis together with the household data, the timeframe of the research was extended.

The sequential method was realized in two phases. In the first phase, a standard survey of constructed and open and closed questionnaires was carried out. The results were categorized and accordingly "focus groups" were designed in order to get more involved opinions from the inhabitants. After the focus groups, in which the theme of focus and opinions were collected, deepinterviews were held with selected participants from the focus groups. In this two phase study, participants who were the inhabitants of local neighborhoods voluntarily worked with the researcher on specifying their opinions, experiences, information and expectations on the theme in their neighborhoods. These two phases strengthened the data progressively. 
Table 5: $\quad$ Validity of data from urban site mixed research.

\begin{tabular}{|c|c|c|c|}
\hline $\begin{array}{l}\text { PARAMETERES USED } \\
\text { IN THE RESEARCH } \\
\end{array}$ & \multicolumn{3}{|c|}{ NEIGHBORHOODS } \\
\hline INFRASTRUCTURE & ÇELİKTEPE & TALATPAŞA & NURTEPE \\
\hline Health Service Access & 2 & 1 & 1 \\
\hline Education Service Access & 3 & 1 & 1 \\
\hline Water, Electricity, Gas Access & 3 & 3 & 3 \\
\hline Housing & 1 & 1 & 1 \\
\hline Transportation & 3 & 1 & 2 \\
\hline $\begin{array}{l}\text { Cultural and Sports Activities } \\
\text { Access }\end{array}$ & 3 & 1 & 2 \\
\hline \multicolumn{4}{|l|}{ SOCIAL ORGANIZATION } \\
\hline Family Relation & 2 & 3 & 3 \\
\hline Kinship Relation & 2 & 3 & 3 \\
\hline Citizenry & 2 & 3 & 3 \\
\hline Belonging (neighbourhood) & 2 & 3 & 3 \\
\hline Satisfaction (neighbourhood) & 3 & 2 & 3 \\
\hline Satisfaction (administration) & 2 & 3 & 1 \\
\hline Participation (local, central) & 1 & 1 & 3 \\
\hline Usage of Public Spaces & 1 & 1 & 1 \\
\hline Group activities & 1 & 1 & 3 \\
\hline Capacity of Solidarity & 1 & 1 & 3 \\
\hline \multicolumn{4}{|l|}{$\begin{array}{l}\text { SOCIAL RISK AND } \\
\text { VULNURABILITY } \\
\end{array}$} \\
\hline Belonging & 2 & 1 & 1 \\
\hline Conflict & 1 & 1 & 3 \\
\hline Gang Grouping & 2 & 1 & 3 \\
\hline \multicolumn{4}{|l|}{ NEEDS/PROPOSALS } \\
\hline Housing & 3 & 3 & 3 \\
\hline Employment & 3 & 3 & 3 \\
\hline Health & 3 & 3 & 3 \\
\hline Education & 3 & 3 & 3 \\
\hline Security & 1 & 1 & 1 \\
\hline Environmental Quality & 3 & 3 & 3 \\
\hline Capacity of Solidarity & 3 & 3 & 1 \\
\hline
\end{tabular}


Table 5: $\quad$ Continued.

\begin{tabular}{|l|l|l|l|}
\hline PARAMETERES USED & \multicolumn{3}{|c|}{ NEIGHBORHOODS } \\
IN THE RESEARCH & ÇELIKTTEPE & TALATPAŞA & NURTEPE \\
\hline INFRASTRUCTURE & \multicolumn{3}{|c|}{} \\
\hline $\begin{array}{l}\text { EXPECTATION FOR URBAN } \\
\text { TRANSFORMATION }\end{array}$ & 3 & 3 & 1 \\
\hline Needs for Transformation & 3 & 1 & 3 \\
\hline Fear of Transformation & 1 & 1 & 1 \\
\hline $\begin{array}{l}\text { Willingness To Participate in Urban } \\
\text { Transformation }\end{array}$ & 1 & 1 & 1 \\
\hline $\begin{array}{l}\text { Information of Urban } \\
\text { Transformation }\end{array}$ & \multicolumn{3}{|c|}{} \\
\hline
\end{tabular}

It was important to collect quantitative data not only to make sure that enough data was collected but also to ensure the neutrality of data given the pressure created by expectations of what the government's policy of urban transformation entails. The spatial politics concerning this policy in Kağtthane (and also in Istanbul as a whole) inspired intense reactions that the qualitative methods had difficulty capturing and revealing. Our experience of such urban conditions indicated that quantitative methods were more flexible in terms of adding questions or adding other data in order to validate the current data or any necessary changes in modes of data collection.

The content analysis of the qualitative data was mostly done manually, which if it had been done through the use of software would have saved much time. The significance level test and the discourse analysis were meshed and approved (see Table 2). The sequential mixed methodology led to an expanding of the numbers of the focus group and its themes. This was a disadvantage, which ended up requiring more time in the reduction of data. Furthermore, as the urban sites are under large-scale speculation and the pressure of earthquake policy, which will lead to huge urban transformation projects, the psychological state of the citizens (inhabitants) is ambiguous. The ambiguity of their expectations, perceptions and questions concerning the future of their residences made the process of validating the meanings more difficult.

The mixed method process also made it necessary to re-design the flow of questions for each leading participant after combining the data and selecting who would participate.

In this research, mixed methods were used sequentially in order to understand the expectations, perceptions and embedded knowledge about place in Kağıthane, an area, which is under the pressure of urban transformation policies. In Istanbul in the last 10 years, the decision-making process for inhabitants and communities has become more complex due to the pressure and threats of local and central authorities as regards urban transformation policies. Numerous actors exist, and within this context the targets of urban transformation and the influences pulling and pushing the real-estate market have become increasingly 
complex. However, for a sustainable and grassroots-based urban transformation, which will protect and sustain socio-spatial networks, local knowledge and opinions must be taken into account. Thus, these data could only be gathered via mixed methodology process, which has its own outcome and dual experience according the complex urban conditions and actors.

\section{References}

[1] Smith, N. New Globalism, New Urbanism, New Urbanism: Gentrification as Global Urban Strategy, Antipode A Radical Journal of Geography, Vol.34, Issue 3, pp. 427-450, 2002

[2] Balaban, O. Neoliberal Yeniden Yapılanmanın Türkiye Kentleşmesine Bir Diğer Armağanı: Kentsel Dönüşümde Güncelin Gerisinde Kalmak (chapter 1). Istanbul: Müstesna Kentin İstisna Hali (Istanbul Urban Transformation as a State of Exception), eds. P. Tan and A. Cavdar, Hayy Publishing: Istanbul. (Forthcoming, May 2013). Further reference: Capital Accumulation, The State And The Production of Built Environment: The Case of Turkey, O. Balaban, unpublished PhD thesis (METU - 2008)

[3] Harvey, D. Spaces of Global Capitalism: A Theory of Uneven Geographical Development, Verso Publication, New York, pp. 102

[4] Özçevik, Ö., Türk, Ş.Ş., Beygo, C., Taş, E. and Yaman, H., İstanbul'da Deprem Odaklı Dönüşüm Projesinin Ana Bileşenlerinin Analizi: Zeytinburnu İETT Blokları Örneği, ITÜ Journal, Series a, 6(1), İstanbul, pp. 81-94, 2007

[5] Onwuegbuzie, A., Leech, N.L, Linking Research Questions to Mixed Methods Data Analysis Procedure The Qualitative Report Volume 11 Number 3 September 2006 referencing in Collins, K. M. T., Onwuegbuzie, A. J., and Sutton, I. L., A model incorporating the rationale and purpose for conducting mixed methods research in special education and beyond. Learning Disabilities: A Contemporary Journal, 4, 67-100, 2006

[6] Hewson, C., Mixed-Methods, in V. Jupp (Ed.), The Sage Dictionary of Social Research Methods, Sage Publication, London, pp. 179-180, 2006

[7] Creswell, J.W., Research Design - Qualitative, Quantitative and Mixed Methods Approaches, Sage Publication, London, p. 230, 2009

[8] Creswell, J.W., Research Design - Qualitative, Quantitative and Mixed Methods Approaches, Sage Publication, London, p.14, 2009

[9] Creswell, J.W. and Clark, P. referencing in Driscoll, D., Appiah-Yeboah, A., Salib, P., Rupert, D.J. Merging Qualitative and Quantitative Data in Mixed Methods Research: How To and Why Not, Ecological and Environmental Anthropology, 3(1), pp. 118-121, 2007

[10] Hewson, C., Mixed-Methods, in V. Jupp (Ed.), The Sage Dictionary of Social Research Methods, Sage Publication, London, pp. 180, 2006 